\title{
EDITORIAL
}

\section{A Fresh Look at Teaching International Law-A Few Pedagogical Considerations in the Age of Communications}

TARCISIO GAZZINI*

\section{INTRODUCTION}

This editorial takes a practical approach. It aims to stimulate reflections on the way we teach international law today, on how new technologies could enhance the pedagogical experience, on the upgrading of the role and participation of students, and on a better connection with the 'real world'. It focuses on 'how' rather than on 'what' or 'for what purpose' we teach international law. With this aim in mind, it serves a few ideas seasoned with suggestions and examples. ${ }^{\text {I }}$

Five preliminary considerations are in order. First, frontal teaching remains the backbone of offline higher education taught programmes and one of the most effective methods for the transmission of knowledge, although too-large classes pose serious problems. Second, not all pedagogical tools mentioned here are suitable to all levels, types and formats of higher education, or compatible with available resources. Third, new technologies must retain a complementary nature without any pretention to replace or reduce the role of teachers. Fourth, this editorial has no ambition to provide a comprehensive treatment of the tools available to teachers. Last but not least, although several of the considerations herein may have general character and apply to many if not all disciplines, they retain a special value for international law due to the truly global dimension that distinguishes it. This makes

\footnotetext{
Senior researcher, University of Lausanne [tarcisio.gazzini@unil.ch].

In general, see the work of the International Law Association Committee on Teaching International Law, at www.ila-hq.org/en/committees/index.cfm/cid/ıoog, as well as the reflections of the Interest Group, at www.ila-hq.org/en/study-groups/index.cfm/cid/I038. Scholarly studies on teaching international law are abundant, see in particular B. Cheng (ed.), International Law: Teaching and Practice (I982); M. Lachs, The Teacher in International Law: Teachings and Teaching (I987); B. Broms, 'International Law in the Law School Curriculum', in R. St.J. Macdonald (ed.), Essays in Honour of Wang Tieya (I994), 79; B. Cheng, 'How should we study international law?', (I994-I995) I3 Chinese Yearbook of International Law \& Affairs 2 I 4; A. Orford, 'Citizenship, Sovereignty and Globalisation: Teaching International Law in the Post-Soviet Era', (I995) 6 Legal Education Review 25 I; J. Gamble and C.C. Joyner, Teaching International Law: Approaches and Perspectives (I997); M.W. Reisman, 'The Teaching of International Law in the Eighties', (I996) 20 International Lawyer 987; G. Simpson, 'On the Magic Mountain: Teaching Public International Law' (I999) Io EJIL 22; E. Hey, Teaching International Law: State Consent As Consent to a Process of Normative Development and Ensuing Problems (2003); J.R. Maxeiner, 'Learning from Others: Sustaining the Internationalization and Globalization of U.S. Law School Curriculums', (2008) 32 Fordham International Law Journal 32; J. Klabbers and M. Sellers (eds.), The Internationalization of Law and Legal Education (2008).
} 
international law the perfect laboratory for a reflexion on teaching in the age of communications. Considering the Eurocentric origins of international law and the heavy influence of Roman law, enlarging the learning community, developing new activities and exploiting the potential of new technologies will facilitate the crossfertilization of legal traditions, give voice to different experiences and approaches and ultimately broaden the horizons of the learning experience.

\section{IN THE CLASSROOM}

There are a variety of tools that teachers may use in the classroom. Probably all teachers use, in different formats, for different purposes and to different extents, materials liable to make their lectures more stimulating, the transmission of knowledge more efficient, their arguments more persuasive and the participation of students more active.

These tools may be static and include a variety of documents such as international treaties, judicial decisions, resolutions of international organizations as well as organizational charts of international organizations, ${ }^{2}$ geographical maps or technical drawings useful to examine international decisions, projects, production processes, or crises, ${ }^{3}$ or charts of dispute settlement mechanisms. ${ }^{4}$ The value of these materials is self-evident; they make the lecture more lively, ensure greater accuracy, introduce discipline with regard to questions, comments and discussions, and familiarize students with primary sources and official documents.

Other documents are prepared beforehand by teachers and may be made available to students, presumably in electronic format. Intended to accompany the teacher's presentation, they may be visualized in the classroom through old fashioned projectors or their increasingly sophisticated electronic equivalents. Their content may range from a sketchy framework of the lecture to a detailed logical sequence of the arguments discussed during the lecture.

For some, these documents are useful as they allow the teacher to explain and follow the objectives, structure and logical steps of the lecture, to efficiently manage time and to offer students a convenient visual aid with clear points of reference (typically a Power Point document). Other teachers doubt the utility of these documents, or even see in them potential restrictions to their freedom to model and adapt the lecture to the students' needs, responses and interests. These teachers may tend to prefer to use the traditional blackboard, whiteboard and any other electronic equivalent visual aids.

2 See, for instance, the United Nations Chart at www.un.org/depts/dhl/deplib/promo-materials/ UNsystemChart-lt-clr.pdf.

3 See, for instance, the sketches included in North Sea Continental Shelf Cases (Federal Republic of Germany/ Denmark; Federal Republic of Germany/Netherlands), Judgment of 20 February I969, [I969] ICJ Rep. 3, at I5I6; or the route of the North Stream pipeline, at www.nord-stream.com/press-info/images/nord-streampipeline-reinforcing-gas-supplies-to-northwest-europe-3487; or the process to extract shale gas, Shale Gas Information Platform, 'What is Shale Gas', at www.shale-gas-information-platform.org/what-is-shale-gas.html; or the evolution of the conflict in Syria, at syria.liveuamap.com.

4 See, for instance, World Trade Organization (WTO), The Panel Process, at www.wto.org/english/thewto_e/ whatis_e/tif_e/disp2_e.htm. 
The blackboard - or its technologically advanced equivalents - is still dear to many teachers as it offers the opportunity to interact with students during the lecture in the attempt to graphically represent and conceptualize specific questions or issues through taxonomy, charts, tables and any other appropriate form. These techniques may conveniently be used, for instance, to discuss the relationships between different legal sources, to identify a plurality of stakeholders and assess their competing interests, to categorize and compare different legal remedies, or to illustrate the different procedural steps of an international dispute mechanism. They may ultimately encourage the participation of students and invigorate the interaction between themselves and with the teachers.

Even more challenging is the use in the classroom of websites and videos, with motion expected to capture better than anything else the students' attention, curiosity and observational spirit. Provided that their use remains reasonable in terms of time, the potential of websites and videos is enormous. A couple of examples suffice.

In its simplest application, the teacher, instead of providing directly the text of a treaty (or a judgment or a resolution) retrieves it from the relevant official website. ${ }^{5}$ Time allowing, retrieving any such document may be the pretext for a short virtual visit to the relevant website. From this perspective, during the lecture on the law of the treaties, the teacher becomes the unofficial guide to the United Nations Treaty Series (UNTS) website and explains how to search for a treaty and related status of ratification, how to double-check reservations and so on. During a seminar on the World Bank, the teacher searches the virtual database of the Bank for the financed projects, the related data and the typical official documents prepared throughout the life of a project. Another interesting destination is the website of the International Court of Justice, where students discover how states may accept the jurisdiction of the Court, how the Court operates and what products it delivers. From this perspective, the wealth and heterogeneity of the subjects and participants typical of the international legal order not only make the exercise more stimulating but also transforms it into a virtual global journey through different multicultural legal environments.

Needless to say, videos may be formidable complements to lectures. Often a short video can make, in a couple of minutes, a point more efficiently than lengthy explanations, or simply fortify it and permanently record it in the audience's memory. How to explain that state borders have constantly and in some epochs even frantically changed better than with a time-lapse covering their evolution since 1648 or during any other significant period? ${ }^{6}$ How to explain the difficulties of establishing the real origins of a product better than with a WTO official video on the value chain of

5 A treaty can be retrieved from the UNTS website, at treaties.un.org/Pages/UNTSOnline.aspx?id=I, or a national website such as the United Kingdom Treaty Series, at treaties.fco.gov.uk/treaties/treaty. htm;jsessionid=BFB7 I29IC047B750B207CA564AE7B32B; a Security Council Resolution from the organ's website, at www.un.org/en/sc/documents/resolutions/; and a judgment of the International Court of Justice from www.icj-cij.org/docket/index.php?pi=3.

6 See, for instance, 'Time-lapse of Europe's changing borders since I Ioo AD Westphalia', at www.dailymail. co.uk/video/sciencetech/video-I093I78/Time-lapse-Europes-changing-borders-I IooAD.html (not entirely accurate but still quite useful). 
a popular smart phone?7 How to illustrate the difficulties in applying in practice the basic principle of distinction between combatants and civilians in international humanitarian law better than showing an official video of a military air strike taken from a fighter? ${ }^{8}$

Social media will eventually break into the classroom and offer innovative teaching techniques, more dynamic forms of participation by students and challenging opportunities of interaction between teachers and students. In the simplest form, students may contribute to the lecture by sending their questions, comments and reflections. It may be expected that students are so familiar with writing short answers, comments or questions that they are able to do so in the classroom without losing focus on or disrupting the lecture.

Social media not only provides an efficient and orderly manner to channel students' inputs but also encourages a much larger participation to the lecture. Social media may even salvage classes in which the attendance has reached such proportions that participation becomes inexorably passive and the interaction between teachers and students unavoidably tends to disappear. The impact of social media is amplified if the lecture is live streamed. In this case, students not physically present in the classroom are in a position to intervene too.

Students can also use social media to convey their reaction with regard, for instance, to the persuasiveness of the argument developed by the teacher, of a decision rendered by tribunals (including opinions of dissenting judges), or of official legal positions taken by governments. Social media can even be used to disclose the evolution of the students' perception of or attitude related to any legal problem or issue by comparing their orientation before and after the lecture or the discussion.

The real challenge is to ensure that the use of social media is fully and logically integrated in the lecture. Contributions through social media need to be complementary to the traditional forms of interaction between teacher and students (questions, comments, requests for clarification, discussions and so on). They can be solicited but can also be unsolicited, thus allowing students to put forward their ideas at any time in a convenient and effective manner. The management of the students' input, however, probably requires the presence of an assistant responsible for filtering, grouping and selecting them. If properly managed, social media may have important potential in terms of enhancing the learning experience and bringing it in line with current societal and technological evolution. Its use for teaching purposes, after all, may be less revolutionary than it might appear at first sight.

\section{ON THE PLATFORM}

New technologies have expanded the teaching space well beyond classrooms. This has occurred in particular with the creation of virtual platforms such as Moodle.

See, for instance, the official video obtained by the German magazine Bild, WTO, Made in the World, at www.youtube.com/watch?v=KMkJu8S8ztE, at I:49.

8 See, for instance, Bild, 'At r:49 the bombs hit the trucks', at www.bild.de/news/bild-english/how-deadlyafghan-bombing-scandal-covered-up-in-germany-I0626064.bild.html. 
These platforms may, in the first place, serve as a channel of communication and for the transmission of documents between teachers and students. They ensure a continuous and efficient flow of information and documents, such as syllabuses, outlines, handouts, bibliographic indications, presentations, information about conferences, calls for papers and so on. The materials made available on the platform may also include relevant videos, links to websites, or online teaching available to the public. ${ }^{9}$ They do not need to be always serious as sometimes a perspicacious cartoon or a clever clip can at once make the entire experience more enjoyable and trigger a reflection or stimulate a debate. ${ }^{\text {IO }}$ Incidentally, the borders between reality and entertainment are today more open than ever to unexpectedly clever and fruitful incursions. ${ }^{\text {II }}$ The platform may even further open the horizon of the experience and contain a section on movies, documentaries or novels related to any question in the syllabus. ${ }^{\mathrm{I}}$

The platform also offers the opportunity to create a forum, presumably with the moderation of teachers or assistants, in which the course or programme community can interact and exchange views. Access to the forum may be limited to the students enrolled in the course or programme. It may also be extended to a broader community of students, including online students, or even beyond academia (practitioners, judges, legal advisors, civil servants, diplomats and so on).

Finally, the platform may serve to publish short notes, not necessarily conforming to the formal standard of academic reviews, providing short comments on landmark decisions, important legislative developments, international crises, or any other legal issues, and ultimately ignite and stimulate a debate.

\section{Parallel activities}

In addition to the activities in the classroom and on the platform, a plethora of parallel student-centred activities may be included in the course or programme with a view to making the learning experience more practice-oriented and exciting. Some of these activities are already well established, especially in Anglo-Saxon institutions.

They include moot courts and role playing activities aimed at developing students' abilities in preparing written and oral submissions, to practice in pleading before would-be international tribunals, ${ }^{\mathrm{I} 3}$ to apply their theoretical knowledge in practical simulations and exercises, such as, for example, radio interviews on a judicial case or

9 See, for instance, United Nations, Audio-visual Library of International Law, at www.un.org/law/avl/.

ro See, for instance, S. Fry, H. Laurie and Friends, The Treaty of Westphalia, at www.youtube.com/watch? $\mathrm{v}=\mathrm{c}-\mathrm{WO}_{73} \mathrm{Dh} 7 \mathrm{rY}$.

II Interestingly, in Paeste v. Government of Guam, the United States Court of Appeals for the Ninth District (Opinion Judge Berzon) at cdn.cag.uscourts.gov/datastore/opinions/2015/08/26/I3-I5389.pdf, made a reference to Last Week Tonight with John Oliver. U.S. Territories, 8 March 2015, at www.youtube.com/ watch? $\mathrm{v}=$ CesHrggezWE.

I2 Amongst many examples, see F. Lang, M(I93 I); E. Kusturica, Underground (I 995); W. Herzog's documentary, Lessons of Darkness (I992); S. Townsend, Battle in Seattle (2007); A. Gibney, Enron: The Smartest Guys in the Room (2006).

I3 Amongst several examples, see Willem C. Vis International Commercial Arbitration Moot, at vismoot.pace.edu; Frankfurt Investment Arbitration Moot Court, at www.investmentmoot.org; Philip C. Jes- 
legal issue, intervention in the debate before organs of international organizations, or visits to a prisoner of war camp as a delegate of the International Committee of the Red Cross. ${ }^{\text {I4 }}$

Law clinics, in turn, are powerful instruments to develop practical skills and building bridges between academia and professional practice. Although their success in the United States is well documented, ${ }^{15}$ law clinics have not yet found a particularly fertile ground in Europe, with significant exceptions. ${ }^{\text {I6 }}$

Another important parallel activity students may profitably be involved in is editorship. American journals have a long tradition in this regard, but in Europe the opportunities for students to contribute to the management of journals remain relatively rare, again with important exceptions, including this journal, whose editorial board benefits from the assistance of several graduate students. ${ }^{17}$

Students may also enhance their learning experience and develop their organizational skills by organizing events with academics, judges, practitioners and other professionals working in the international legal arena. Aimed at discussing topical or challenging legal questions, these events may take a variety of forms, including roundtables, informal workshops, movie screenings followed by interventions, or debates open to the public. The latter are well established in the Anglo-Saxon academic tradition, but struggle to find their way into continental Europe.

A final activity relates to empirical research or collection of data for the compilation of digests of domestic or international decisions or State practice. A good example is the mapping exercise currently conducted by UNCTAD, which aims at provide a systematic mapping of investment treaties. ${ }^{18}$ The exercise has two distinct advantages from the standpoint of students. On the one hand, students have a challenging opportunity to work on primary sources; on the other hand, they broaden their horizons and discover the world of intergovernmental organizations.

\section{Online teaching}

Last but certainly not least, there is online teaching. Online teaching can be structured in a variety of ways and often combines different elements. The transfer of knowledge, in particular, can take the form of recorded videos, specifically designed materials, training module or exercises. While theoretical and empirical studies

sup International Law Moot Court Competition, at www.ilsa.org/jessuphome; and Concours Jean-Pictet, at www.concourspictet.org.

I4 See, for instance, Model United Nations, at model-unitednations.org; and the Frits Kalshoven Competition, at www.rodekruis.nl/dit-zijn-we/humanitair-oorlogsrecht/ihlcompetition.

I5 See, in particular, A.J. Harno, Legal Education in the United States (2004); F.S. Bloch (ed.), The Global Clinical Movement: Educating Lawyers for Social Justice (20 I I).

I6 For two successful examples, see the Trade and Investment Law Clinic, Graduate Institute of International and Development Studies, Geneva, at graduateinstitute.ch/trade-law-clinic, and the Amsterdam International Law Clinic at the University of Amsterdam, at ailc.uva.nl.

I7 Another and quite different example is the student-run Amsterdam Law Forum, at amsterdamlawforum.org.

I8 UNCTAD International Investment Agreements Mapping Project, at investmentpolicyhub.unctad.org/ Upload/Documents/UNCTAD\%20IIA\%20MAPPING\%20PROJECT\%2020I3-20I4.pdf. 
on online teaching are abundant today, ${ }^{\text {I9 }}$ a few considerations are relevant for our purpose here.

In the first place and whatever the format, ${ }^{20}$ online teaching tears down all space limitations and exponentially increases the reach of courses and programmes, with the potential - not yet properly exploited ${ }^{2 I}$ - to enhance the democratization of access to higher education. Online teaching also expands the learning community and paves the way to interaction between online and offline students, who may find in the platform a boundless virtual space to exchange views, materials and experiences.

Secondly, while offline teaching retains several comparative advantages - most prominently the personal contact between teacher and students - online teaching has its own advantages. Rather surprisingly, the most important one is probably the enhanced - if not compulsory - active participation of students, especially in the form of written submissions as well as oral or text contributions to fora. It has been pointed out that online teaching obliges all students to get actively involved in the learning process, even those that in a classroom may be reluctant to intervene or never do so. ${ }^{22}$

Third, online and offline teaching will increasingly contaminate each other and tend to merge into a unique experience with an enlarged heterogeneous community continuously interacting.

\section{Conclusions}

The teaching experience in international law - like in any other field - has evolved and is still evolving with increasing rapidity. New technologies have created new spaces, enlarged communities, introduced new forms of interaction, and provided new opportunities for developing professional skills. All these developments have enormous potential and can make the teaching experience more challenging, exciting and enriching.

Three elements are crucial to exploit such potential. First, schools of law must be ready to explore without preconceptions the use of new technologies and carefully consider the necessary commitment of resources. Second, they have to ensure that

I9 See in particular, J. Stephenson, Teaching \& Learning Online: Pedagogies for New Technologies (200I); G. Salmon, E-moderating: The Key to Teaching and Learning Online (2004); S. Bach, P. Haynes and J. Lewis Smith, Online Learning And Teaching In Higher Education (2007); R.M. Lehman and S.C.O. Conceição, Creating a Sense of Presence in Online Teaching: How to 'Be There' for Distance Learners (2010); C. Howell Major, Teaching Online: A Guide to Theory, Research, and Practice (2016).

20 Compare, for instance, the Massive Open Online Course dedicated to International Law on the edX platform, recently launched by the University of Louvain (UCL), at www.uclouvain.be/5 I I $270 . h$ tml; the International Law course offered by the New York University School of Law, Institute for International Law and Justice, at www.iilj.org/courses/InternationalLawCourse.asp, and the courses provided by UNITAR, at www.unitar.org/programme-area.

2I On the, so far, rather unfulfilled high expectations of Massive Open Online Courses (MOOCs) in developing countries, see, for instance, T. Liyanagunawardena, S. Williams and A. Adams, The impact and reach of MOOCs: a developing countries' perspective, (2013) 33 eLearning Papers; M. Trucano, More about MOOCs and Developing Countries, I 2 November 2013, at blogs.worldbank.org/edutech/moocs-developing-countries.

22 D. Koller, 'What we're learning from online education', TED Talks, 20I2, at www.ted.com/talks/daphne koller_what_we_re_learning_from_online_education?language=en. 
curricula and syllabuses are flexible enough to accommodate new activities, if necessary by granting those participating in these activities academic credits equivalent to comparable academic courses. Third, they should seize these opportunities to intensify their efforts to build bridges with the world outside academia, professionals in international law in particular. 